\title{
Plans for $\mathbf{N}$-test simulators trigger reaction
}

Paris. A shift in the focus of France's nuclear weapons research programme from developing nuclear weapons to simulating nuclear explosions is prompting a major reorganization of the Direction des Applications Militaires (DAM), the defence arm of the French Atomic Energy Commission (CEA), which announced last week that it is to shed one-fifth of its 5,700 staff over the next decade.

But France's decision, like that of other nuclear weapons states, to shift its weapons research to simulation techniques remains controversial. In particular, critics such as the Nuclear Control Center in Washington DC claim that such techniques - and lasers in particular - could be used to design new nuclear warheads.

The shift in research goals follows President Jacques Chirac's recent decision both to cease nuclear testing and to make major cuts to France's nuclear weapons programme. Addressing the nation on a major reform of the armed forces, Chirac confirmed that France would retain its nuclear deterrent as an ultimate defence. But he added that the scope of its nuclear weapons activity would be reduced to a minimum.

The brunt of the cuts will be borne by DAM, which will close two research centres, at Limeil and Vaujours, and regroup its activities in its four remaining laboratories, at Valduc, Ripault, Bruyères-le-Chatel and Le Barp. According to Jacques Bouchard, director of DAM, however, most of the cuts will fall on activities connected with developing nuclear weapons, and not on research.

Indeed, while overall staff numbers are being reduced, Bouchard says that he will still be able to increase the recruitment of scientists to nuclear simulation research, as many DAM staff will retire soon.

Similarly, France's investment in simula-

tion is set to grow. It will spend FF150 million (US $\$ 30$ million) this year on supercomputers, for example, and will invest a further FF750 million on Airix, a powerful X-ray machine used to study the behaviour of heavy metals during implosion of chemical explosives.

The Centre d'Etudes Scientifiques et Techniques d'Aquitaine (CESTA) at Le Barp, near Bordeaux, will be the lynchpin of DAM's new strategy. It will house the FF6-billion 1.8-megajoule laser being built as part of French plans to carry out nuclear weapons research without having to carry out nuclear tests of its hydrogen bombs (see Nature $\mathbf{3 7 5}$, 6; 1995). To build the Megajoule laser, DAM is collaborating with the Lawrence Livermore National Laboratory in California, where a similar facility, the National Ignition Facility (NIF), is to be built.

Bouchard dismisses claims that the simulation techniques might be used to design new warheads. He argues that simulation will be used only to renew existing weapons in the stockpile and to allow minor modifications to warheads, for example, to fit improved missiles. Simulation is needed, he says, to maintain a critical mass of competence in nuclear weapons that will in turn ensure that the reliability of the existing stockpile is maintained.

Indeed, many US weapons experts, including Richard Garwin, IBM Fellow Emeritus at the Thomas J. Watson Research Center in Yorktown Heights, New York, agree that while rudimentary weapons could be designed without testing, nuclear weapons states have no interest in adding such weapons to their stockpile, as they already possess reliable high-performance weapons.

Another concern raised by Theodore

\section{France seeks to clean up nuclear image}

Paris. President Jacques Chirac's announcement of a unilateral reduction in France's nuclear weapons capacity, issued on the eve of the first major summit between European and Asian nations, was clearly intended to restore France's international reputation following the damage done last year by its decision to proceed with a series of nuclear tests in the South Pacific. Ironically, Chirac is now presenting France as the champion of nuclear disarmament.

The reduction will include the dismantling of France's 18 one-megaton silobased missiles on the Plateau d'Albion, and 40 mobile 80-kiloton Hadès missiles. Its nuclear deterrent will now consist primarily of a modernized fleet of four nuclear submarines, with a few dozen aircraft. France will also stop producing weapons-grade fissile material, and will close its plants at Pierrelatte and Marcoule; it has stocks to meet anticipated needs for at least 50 years.

Chirac reiterated his commitment to supporting a ban on all nuclear tests, no matter how small (see Nature 376, 540; 1995). He also announced that France would close for good its nuclear testing sites at Mururoa and Fangataufa in the South Pacific.

In taking this action, Chirac has preempted other nuclear weapons states, which have also promised to sign the Comprehensive Test Ban Treaty (see Nature 376, 283; 1995), but which have not yet decided definitively to close their testing sites.

D. B.

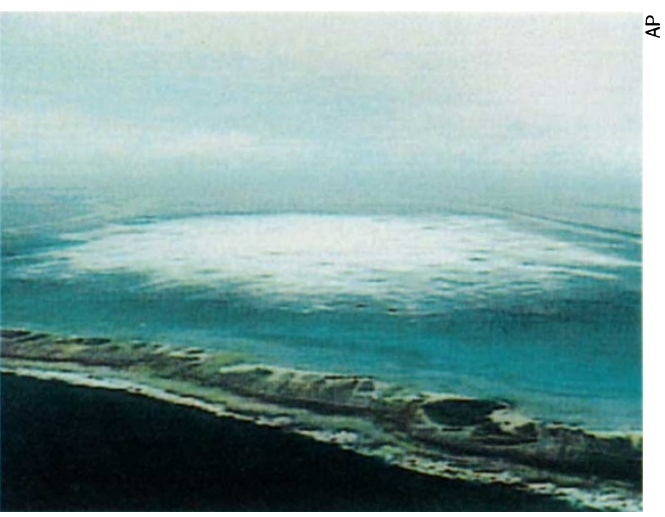

last from the past? France plans to close nuclear esting sites at Fangataufa (above) and Mururoa.
Taylor, a former nuclear weapons designer at the Los Alamos National Laboratory, is that the development of lasers capable of triggering thermonuclear fusion itself poses a new threat of nuclear proliferation.

Taylor claims, for example, that such lasers could be an important step towards designing pure fusion weapons, or directedenergy weapons such as high-power microwave beams, and has called for a ban on the development of the technology.

Bouchard argues that the Megajoule laser can in no way be considered a weapon. "It is simply a big physics instrument," he says. But other critics, such as Venance Journé, from the Centre International de Recherche sur l'Environnement et le Développement (CIRED) in Paris, still complain about what they claim is a lack of adequate information about the nature of planned experiments using the laser.

The secrecy surrounding such projects, she adds, highlights a wider problem, namely the failure of the French government to allow independent scientific experts sufficient access to classified information. "Those who know, don't talk, and those that talk, don't know" is how one observer paraphrases what he claims to be a lack of informed debate in France about the necessity of resuming nuclear testing.

Bouchard says he agrees that sufficient information about nuclear weapons should be made available to allow "real discussion between specialists". At the same time, however, he claims that it is dangerous to provide "too much information in such a sensitive area", arguing that this itself could increase the risk of proliferation.

But Journé contests this, pointing out that the United States allows independent experts access to classified data without jeopardizing national security. For example, a panel of experts convened under the JASON programme last year studied and rejected the case for small nuclear explosions, later releasing an unclassified executive summary of the full classified report (see Nature 376, 540; 1995). Declan Butler 